\title{
Principles for Youth Development
}

Stephen F. Hamilton, Mary Agnes Hamilton, and Karen Pittman

The term youth development is used in at least three different ways, referring to a natural process of development, principles, and practices. All three are important, and they are logically related.

1. A natural process. Youth development has traditionally and is still most widely used to mean a natural process: the growing capacity of a young person to understand and act on the environment. In this usage, it is identical to child or adolescent development. Human development is the natural unfolding of the potential inherent in the human organism in relation to the challenges and supports of the physical and social environment. Development lasts as long as life. Optimal development in youth enables individuals to lead a healthy, satisfying, and productive life, as youth and later as adults, because they gain the competence to earn a living, to engage in civic activities. Both heredity and environment influence the natural unfolding. People can actively shape their own development through the choices they make and interpretations they place on their experiences.

2. Principles. In the 1990s, the term youth development came to be applied to a set of principles, a philosophy or approach emphasizing active support for the growing capacity of young people by individuals, organizations, and institutions, especially a the community level. The youth development approach is rooted in a commitment to enabling all young people to thrive. This simple statement combines two principles: universality or inclusiveness (all youth) and a positive orientation building on strengths (thriving). Youth development arose as a counterbalance to the emphasis in problem prevention and treatment programs on categorizing youth according to their deficits and trying to remedy them. The contrast between a youth development approach and approaches designed to prevent or treat specific kinds of problems among groups of youth identified as being at high risk is somewhat analogous to that between public health and medical treatment. As in the health field, sharp debates and rivalries are often dulled in practice, where, in reality, a blend of both approaches is needed. If all youth are to thrive, some of them need prevention and treatment.

3. Practices. The third use of the term youth development is to describe a range of practices in programs, organizations, and initiatives. Youth development in this sense refers to the application of the principles (Number 2) to a planned set of practices, or activities, that foster the developmental process (Number 1) in young people. The distinction between principles and practices is especially useful when considering the various settings or contexts in which young people spend time. Development takes place in families, neighborhoods, youth organizations, faith- 
based organizations, schools, and a multitude of other places, including cyberspace. Although the specific practices that adults use to create and sustain such opportunities differ across settings, the principles are consistent.

In our terminology, programs, organizations, and initiatives are sequentially larger aggregations of practices. A program may be short-term or long-term. It may involve large or small numbers of youth. It is usually embedded in or sponsored by an organization. An organization is more enduring and has multiple components. Organizations typically engage youth in a range of different programs. For example, a youth in the East Oakland Youth Development Center (see Chapter 2 on youth organizations) might enroll in their arts, employment, and/or physical development programs. By initiative, we mean a multifaceted collaborative effort to enlist the broadest possible set of people and organizations in making communities more conducive to youth development. Two initiatives, Beacons and New Futures Initiatives, are treated in the chapter on communities.

Youth development has also gained prominence as a movement (Pittman, Irby, \& Ferber, 2000) serving as a unifying theme for a wide range of discussions and actions aimed at shaping policy as well as practice. Policy, a fourth "P," refers to a course of action adopted by an organization, especially a government. Youth development principles have informed policy at all levels of government (local, state, and national) and in a variety of different sectors or departments that include a focus on young people. We treat the policy arena throughout the volume because it is relevant to all chapters.

We turn now to youth development as a process, followed by a discussion of the theoretical basis for some of the key youth development principles. We address practices only briefly in this introduction, because the chapters in Part I illustrate effective youth development practices across the range of settings youth inhabit.

\section{The Process and}

\section{Goals of Youth Development}

Development is a process, not a goal. People continue to develop throughout their lifetimes. Therefore, promoting youth development is an enduring, overarching purpose, not a goal that is ever finally achieved. John Dewy (1938) captured this quality by noting that the purpose of development is to enable a person to continue to develop. Viewing development in this way complicates the identification of goals. Rather than setting out concise measurable behaviors, developmental goals identify demands for growth. Progress, opposed to attainment, is the key (Kohlberg \& Mayer, 1972).

This circular quality of development makes it difficult to separate goals from methods for achieving goals. Goals and methods, ends and means, and process and product are intertwined. Because goal setting is such an important part of program planning, we will refer to developmental goals, recognizing that even though such goals are not always amendable to measurable outcomes or behavioral objectives, they can provide a helpful framework to guide action.

Human qualities that we wish to promote can be described in multiple ways. A simple formulation is that development leads to the "Five Cs": competence, character, connections, confidence, and contribution (listed as caring and/or compassion in other 
formulations) (Pittman, Irby, Tolman, Yohalem, \& Ferber, 2002). Competence includes knowledge and skills that enable a person to function more effectively to understand and act on the environment. Competence enables a person to accomplish what he or she intends, provided external circumstances are favorable, or to adapt to circumstances to achieve as much as possible. Character is what makes a person intend to do what is just, right, and good. Connections refer to social relations, especially with adults, but also with peers and with younger children. Confidence is the assuredness a person needs to act effectively. It enables a person to demonstrate and build competence and character in challenging situations. Contribution means that a person uses these other attributes not only for self-centered purposes but also to give to others.

Notice that none of these developmental goals has an upper limit. One is never perfectly competent or of such high character that no further progress is needed. However, it is possible to get out of balance, especially with connections and confidence. We denigrate as a "social butterfly" a person who cares too much about superficial connections, especially when that person seems to sacrifice character, adopting whatever opinions or behaviors are popular. When confidence outruns competence, danger looms. We think of the "Five Cs" as logically linked. Competence and character are central. Young people gain competence and character by being connected with others; especially caring adults, and their competence and character in turn help them form new connections. Confidence flows from competence, and the two mutually reinforce each other. Finally, contributions demonstrate one's character and provide an outlet for competence. (These connections are discussed further in the chapter on work and service.)

The "Five Cs" briefly summarizes the goals of youth development. They are useful as a quick mental checklist when thinking about what a particular program, organization, or initiative offers to youth. They can provide a focus for community-wide initiatives. However, each is broad enough to pose challenges when it comes to designing and evaluating programs. Programs might try to enhance the competence of young people in a multitude of ways and across a range of contexts or settings, making it difficult to know when progress occurs and what led to it. For program-planning purposes, a longer, finergrained analysis of the goals of development is needed.

The Committee on Community-Level Programs for Youth, convened by the National Research Council and Institute of Medicine of the National Academy of Sciences, has provided an authoritative summation of the critical domains of youth development, adopting the terminology of personal and social assets (See Table 1.1). They categorized these assets as physical, intellectual, psychological and emotional, and social development.2

Note that the term asset allows for the same ambiguity we have attributed to developmental goals. Assets are both desirable in themselves (think of cash and real estate) and useful in obtaining other desirable things that may themselves also be assets (buying artwork with cash, using real estate to secure a loan). 
Table 1.1

\section{Personal and Social Assets That Facilitate Positive Youth Development}

\section{Physical Development}

- Good health habits

- Good health risk management skills

\section{Intellectual Development}

- Knowledge of essential life skills

- Knowledge of essential vocational skills

- School success

- Rational habits of mind-critical thinking and reasoning skills

- In-depth knowledge of more than one culture

- Good decision-making skills

- Knowledge of skills needed to navigate through multiple cultural contexts

\section{Psychological and Emotional Development}

- Good mental health, including positive self-regard

- Good emotional self-regulation skills

- Good coping skills

- Good conflict resolution skills

- Mastery motivation and positive achievement motivation

- Confidence in one's personal efficacy

- "Planfulness" - planning for the future and future life events

- Sense of personal autonomy/responsibility for self

- Optimism coupled with realism

- Coherent and positive personal and social identity

- Pro-social and culturally sensitive values

- Spirituality or a sense of a "larger" purpose in life

- Strong moral character

- A commitment to good use of time

\section{Social Development}

- Connectedness-perceived good relationships and trust with parents, peers an some other adults

- Sense of social place/integration-being connected and valued by larger social networks

- Attachment to pro-social/conventional institutions, such as school, church, non-school youth programs

- Ability to navigate in multiple cultural contexts

- Commitment to civic engagement

SOURCE: National Research Council and Institute of Medicine (2002, Box 3-1, pp. 74-75). Reprinted with permission from Community Programs to Promote Youth Development. (C2002 by the National Academy of Sciences, courtesy of the National Academies Press, Washington, D.C. 
If one adds promote or increase to each of the assets listed in the box, they serve well as a list of goals for youth development. The formulation by the Committee on Community-Level Programs for Youth of the key domains of youth development and the implied goals associated with each has several strengths. First, it represents a distillation of available research by distinguished scholars on the qualities of people who succeed by most standards. Second, it provides far more specific targets for youth development that the preceding abbreviated sets of goals. This fuller compilation aids both the design of programs and their evaluation. Third, this list is detailed enough that it distinguishes among and explicates some goals that are at best implicit in the briefer lists, notably, physical and mental health; knowledge, skills, and values that open one to multiple cultures; emotional self-regulation; and spirituality.

On the other hand, a long, detailed set of goals may not necessarily help rally large numbers of people behind a community initiative or serve as a quick reminder of what programs are trying to accomplish. Thus, choosing which list of developmental goals to use depends on how it will be used rather than which one is "correct." The point of presenting both the "Five Cs" and the personal and social assets identified by the Committee on Community-Level Programs for Youth is precisely that they do not conflict. The second expands on and adds detail to the first. The longer list can provide a framework for helping different youth development programs and organizations identify both their unique contributions and the goals they share with others.

The term developmental assets is most closely associated with the Search Institute (Benson, 1997), a not-for-profit organization that conducts research and provides materials, training, and technical assistance to organizations and communities. As pioneers in the youth development movement, the Search Institute found that they could motivate community-wide initiatives around 40 developmental assets (see Table 1.2). Half are external assets that exist to varying degrees in the settings young people inhabit and the people with whom they interact, including family support, safety, adult role models, and creative activities. The other 20 are internal assets that are attributes of young people themselves, such as school engagement, honesty, interpersonal competence, and sense of purpose.

Comparing the Search Institute's list of internal assets with the list produced by the Committee on Community-Level Programs for Youth shows substantial overlap, especially when minor differences in wording are considered The Committee's list, as noted, has the authority of its eminent members and the National Academy of Sciences behind it, along with substantial documentation. The Search Institute has produced a volume substantiating its 40 assets with research, as well (Scales \& Leffert, 1999). Therefore, youth development advocates may use either list with confidence. Although we believe a short list, especially the "Five Cs," may be most effective for rallying community support, the Search Institute has infused its 40 assets into community-wide initiatives. In one community, for example, a grocery store printed the list on shopping bags to remind citizens of what their youth need.

The 40-asset framework is useful in illustrating the circular nature of developmental goals. The research cited indicates that "the more of these assets young people have, the less likely they are to engage in risky behavior... and the more likely they are to engage in positive behaviors" (Scales \& Leffert, 1999, p. 7). But is it helpful to learn that youth who are more engaged in school get better grades? Are these really two different things, 
one an input and the other an output? They appear to be reciprocally related: Students who do better in school are likely to feel more engaged. Distinguishing between what is cause and what is effect muddies discussions about outcomes, which makes goal setting difficult. Perhaps part of the appeal of the asset construct is precisely that we value assets for themselves as well as for their correlation with other desired behaviors and states.

\section{Principles for Promoting Youth Development}

Calling attention to the usage of the term youth development to designate a set of principles is easier than stating those principles precisely. To gain widespread support, any set of principles must be rather broad; specificity is likely to create disagreement. Moreover, as a term spreads, it acquires new meanings, not all of which are universally accepted or even compatible. The youth development principles we find most central and most useful for present purposes are those stated at the beginning of this chapter: the emphasis on a positive approach and universality, or the goal of all youth thriving; the importance of healthy relationships and challenging activities that endure and change over time; and engaging young people as participants, not merely recipients. Others would add to or restate some of the items on this list, but we believe it captures most of what is critical. The following pages provide a theoretical basis for these principles.

\section{All Youth Thrive}

The positive orientation is best understood in contrast to what has been the conventional problem focus of many programs for youth, especially those funded by the federal government. In her path breaking book Adolescents at Risk, Joy Dryfoos (1990) documented the division of federal funding and programs among four major types of problem behavior: teenage pregnancy, substance abuse, delinquency, and school failure. She pointed out that because each problem is the domain of a different federal agency and the source of categorical funding, local prevention and treatment programs mirror the federal structure. Each draws on funding from its own federal agency and applies it to trying to prevent or treat the designated problem in a targeted set of youth, typically those considered at risk of the problem. The system is so well established that each problem also has its own researchers and research literature. In addition to demonstrating a lack of connection among these different enterprises, Dryfoos went on to show that, according to the research in each one, the presumably separate problems and solutions were actually quite closely related. This insight illustrated how shortsighted it is to consider and try to alleviate youth problems (or any human problems) one-at-a-time. Drugs, alcohol, risky sexual behavior, delinquency, school failure, and other problems are best conceived as part of a "problem behavior syndrome" (Jessor \& Jessor, 1977) that often has common roots and is best treated as a whole.

\section{Building on Strengths}

There is another consideration, too, which is that often the best way to solve problems is to build on strengths. This approach has been validated by research on resilient

children, that is, children who grew up under conditions that usually lead to serious 
problems but somehow managed to thrive. (See the treatment of this perspective in the juvenile justice chapter.) Among the drawbacks of emphasizing problems is the selffulfilling prophecy or labeling effect. When youth are selected participate in a program because they are at risk ore enmeshed in problem behavior, selection confirms their identity as troubled. Furthermore, being thrown together with others who are also stigmatized may unintentionally reinforce undesirable behavior. (See “deviancy training” in the peers chapter.)

\section{Universality}

The emphasis on a positive orientation is closely related to the principle of universality. If all youth need support in their development, then participating in a program is no longer stigmatizing. At one extreme, some would say that youth development programs can never be targeted to a defined group and can never engage problem behavior. We reject this extreme. The fact that all youth are developing and their development can be either enhanced or impeded by the opportunities available to them in their families, schools, and communities definitely does not mean that all youth need the same thing. One youth may need a chance to practice leadership skills, while another's most pressing need may be a safe place to spend the night. Applying the principles you youth development to the second youth means that providing a shelter for the night is necessary but not sufficient; he or she needs opportunities for growth as well.

\section{Services, Supports, and Opportunities}

The distinction among services, supports, and opportunities (Pittman et al., 2002) helps illustrate how a positive orientation and universality are consistent with the need for access to individualized treatment. Opportunities should be available to all. Opportunities-to learn, explore, play, express oneself-are, by definition, taken up voluntarily by a young person once they have been made available. This makes them both universal and individualized. The young person selects from among possibilities. Supports are also available to all. Supports include connections between a young person and others; mentoring is a good example. Services are provided for or administered to a young person. They include health care, housing, social services, compulsory schooling, and drug treatment. Most services are available, in principle, to anyone who needs them. Specific services are targeted, but the safety net of services is universal.

The tension between a positive, universal approach and a more problem-focused, targeted approach is vividly represented in practice by two of the organizations that have done the most to apply and disseminate youth development: the Search Institute and the Social Development Research Group at the University of Washington, originators of Communities That Care. Communities That Care draws on a solid and growing base of research in prevention of youth risk behavior (Catalano, Berglund, Ryan, Lonczak, \& Hawkins, 1998; Catalano \& Hawkins, 1996; Developmental Research and Programs, Inc., 2000). A community that uses this approach begins by determining which youth problems are most prevalent relative to other communities and then selects a validated program, or programs, to reduce those problems. In contrast, the Search Institute helps communities to identify their assets and those of their youth and then to work together to 
build both. As a result, it is less prescriptive and less focused on problem identification and reduction. Although financial and other constrains often mean communities must choose between the two, we regard these frameworks as potentially complementary, addressing as the do different aspects of a comprehensive, community-wide youth development initiative (Whitlock \& Hamilton, 2003).

\section{Race, Ethnicity, Class, and Gender}

Youth differ along other lines, too, in addition to the degree of risk they face or the level and type of problem behaviors they engage in. Most notably, they reflect the stratification of society in the United States according to race and ethnicity, social class, and gender. In general, the cultural backgrounds of European American youth and those with other backgrounds, especially African American and Latino, will differ, not totally, but enough to require attention. Yet the experience and meaning of being African American can vary dramatically from one young person to another, even within the same family. Therefore, prescriptions for action tailored to racial categories are of a little use. They are more likely to perpetuate stereotypes than to overcome them.

As in illustration, many mentoring program staff believes that matching young people with adult mentors of their own race is critical. However, the most rigorous empirical test of that assumption, in the context of an experimental evaluation of Big Brothers/Big Sisters (Rhodes, Reddy, \& Grossman, 2002) found no effect for race of mentor on the behavior of young people. The most persuasive post hoc explanation for the lack of difference is that racial matching probably matters a great deal for young people who are grappling with issues of racial identity and of how they cope in a racist society, but it may matter not at all for others who either have not yet begun to grapple with such issues or are doing so with some success in other venues, such as family, school, or religious organization.

Gender is another powerful source of difference. Certainly, for some purposes and at some times, boys and girls need different opportunities and different treatment. But gender is not always primary. We have to be able to recognize and accommodate gender differences while recognizing in that sometimes gender is less important that race or class or age or simply interests and aspirations.

Social class is another major category, closely associated with race and ethnicity, but not identical. Youth development in an impoverished community differs in important ways from youth development in an affluent one. The principles are the same, but the needs and strategies for meeting them may vary enormously. Sometimes, they vary in unexpected ways that test common assumptions about youth needs.

\section{Challenging Activities and Supportive Relationships}

Urie Bronfenbrenner's ecological perspective (Bronfenbrenner, 1979; Bronfenbrenner \& Morris, 1998) provides a solid theoretical grounding for a range of youth development principles, in particular, the importance of engagement in challenging activities and supportive relationships, both of which endure and change over time. For Bronfenbrenner, development means growing competence. (Contrary to Dewey, who 
defined development as inherently positive, Bronfenbrenner sees development as including the loss of capacities, as happens in aging, and dysfunction, which may result from harmful developmental influences.) "The engines of human development," according to Bronfenbrenner, are "proximal processes” (Bronfenbrenner \& Morris, 1998, p.996). Proximal processes are activities that occur regularly over a long period of time and become progressively more complex. Learning to play piano, soccer, and chess are all examples.

Bronfenbrenner's conception of human development suggest that development is generally promoted by engagement in activities that regular and enduring and that are challenging in the sense of increasing in complexity as people gain competence. Such activities may be performed solo with objects (e.g., photography or pottery) or symbols (e.g., writing poetry, writing a computer program) or both (e.g., painting, playing a musical instrument), but often, they also involve relationships with others. Those relationships are also most beneficial when they are regular, enduring, and reciprocal. Although relationships with adults are especially important, relationships with peers and with younger children also contribute to development. Bronfenbrenner's theory explains why playing soccer or chess, learning to dance, or planning on carrying out a community service project are more beneficial developmentally than watching television or gossiping with friends.

Bronfenbrenner conceives of the environment in which development occurs as a set of nested contexts ranging from families and peer groups (microsystems) to the culture and government (macrosystems) and proposes a series of hypotheses about how these contexts or systems interact (Bronfenbrenner, 1979, p.22). Those who would promote youth development can use this conception to understand where a program, organization, or initiative fits among the contexts in which young people develop, and the range of influences on that process. Imagine two young people serving as interns in a hospital in a program like the one described in the chapter on work and service. What is most important for one may be the skills learned while helping patients do their exercises and the chance to learn about a potential career. What matters most for the other may be that the nurse in charge takes a personal interest in him, asks about his progress in school, his family, and his friends, and encourages him to continue his education.

The best-designed program is, by itself, neither the sole nor even the strongest influence on the attitudes and behavior of the participants. Young people are also influenced by their peers, families, neighborhoods, the media, their perceptions of their chances to "make it," and the interactions among all these influences and more. Add to this mix the variety of interests, genetic endowments (including talents and temperament), and previous experiences different people bring with the, and it is no wonder that one hospital intern becomes a physical therapist as a result of the experience, whereas the other takes an entirely different career direction but attributes his success in part to the mentoring he experienced as an intern.

Youth programs and organizations affect participants differently. Outcomes will never be uniform regardless of how good programs and organizations are. Such inescapable differences reinforce the importance of both variety and choice. One activity is not developmentally appropriate and enhancing for all. 


\title{
Youth Participation
}

A corollary to the observation that youth have different interests and needs and therefore respond differently to the same opportunities is that they should have choices about which activities they participate in and they should have a chance to help shape those activities. This principle also follows from Bronfenbrenner's definition of proximal processes as reciprocal. Human beings develop through active engagement with their environment; by making choices and shaping that environment, they also direct their own development. They are more than passive recipients of external influences (Bronfenbrenner, 1979, p. 21).

Development is not simply something that happens to a person; agency refers to the developing person's active involvement in shaping the process of development, for example, by choosing challenging activities and seeking supportive relationships. This conception underlies the principle that youth are participants rather than simply recipients; they are responsible actors. This principle goes by many names, such as youth voice, participation, and empowerment. It is rooted in the rights young people have as citizens of a democracy and in what is most beneficial to their development (Convention on the Rights of the Child, 1989). In addition, when programs engage participants in serious decisions, those programs usually benefit and as a result can be more responsive, more attractive, and more effective (Zeldin, McDaniel, Topitzes, \& Calvert, 2000). The rights of both adults and youth are constrained and balanced by responsibilities. Emphasizing youth engagement and responsibility does not mean leaving young people to make all the decisions all the time. Older youth in general have greater capacity and opportunity to make decisions that affect themselves and others than do young children. (See chapter on youth organizations.)

\section{Practices for Promoting Youth Development}

If the foregoing principles are valid, then putting them into practice will promote youth development. This assertion is consistent with the recommendation of the Committee on Community-Level Programs for Youth (National Research Council and Institute of Medicine, 2002, Table 4-1, pp. 90-91; see Table 1.3), which produced a list of features of settings that promote youth development based on the best available research:

\author{
Physical and Psychological Safety \\ Appropriate Structure \\ Supportive Relationships \\ Opportunities to Belong \\ Positive Social Norms \\ Support for Efficacy and Mattering \\ Opportunities for Skill Building \\ Integration of Family, School, and Community Efforts
}

According to the Committee, these features are associated with progress toward the developmental goals they identified (i.e., "assets"). Note that these features correspond to 
the Search Institute's 20 "external assets" and are also quite consistent with the principles of youth development state at the beginning of this chapter. This list also echoes Maslow's (1970) hierarchy of human needs, which begins with survival needs and proceeds to self-actualization. We have not emphasized safety, but it is clearly fundamental.

The challenge to practitioners is to figure out how to create environments that bring these features to life. The last feature, "integration of family, school, and community efforts," raises an added and exceptionally complex set of issues. It recalls Bronfenbrenner's (1979) enumeration of the different systems that comprise the ecology of human development and his propositions about the value of connections among them. Trying to integrate efforts across settings involves building systems in the sense of linked and mutually reinforcing places that promote the development of all.

The term community youth development is often used to capture this aspect of youth development, emphasizing what we call community-wide initiatives (Villarruel, Perkins, Borden, \& Keith, 2003). For some, this modifier seems redundant because by definition, youth development entails attempts to make communities healthier places for youth to live and grow. However, we find it helpful because it distinguishes community-wide mobilization from efforts within individual programs or organizations. Many of the illustrations in the chapters describe youth development programs in larger organizations (e.g., faith-based organizations and parks and recreation departments) and organizations that have additional purposes (e.g., juvenile justice). Although we do not include a community-wide focus as a critical component of our basic definition of youth development, the importance of the community is emphasized in the chapters on neighborhoods and community-wide initiatives.

Youth development is more than helping one young person at a time; it entails the creation of a range of contexts or settings, including people and activities that promote youth development. Ideally, they constitute a system in the sense that they are inclusive, enduring, connected to each other, and connected to the larger macrosystem that surrounds them (e.g., labor, market, government, mass media). This definition of a system as inclusive, internally coherent, connected to other systems, and enduring (Hamilton \& Hamilton, 1999, p. 7) differentiates a system from a program. First, a system is inclusive by being large enough to accommodate all those who qualify. A public school system, for example, which must find classroom space and teachers for every first grader who enrolls each fall, may be contrasted with a Head Start program, which typically turns away half to thirds of eligible applicants. Second, a system is internally coherent. It provides guidance to participants on how to move through it, and what a person does in one part of the system counts in another. An after-school program that is systematic is more than a menu of activities. Students can move sequentially through increasingly complex activities, taking more responsibility as they go, just as Algebra II builds on Algebra I. Third, a system is externally connected, or formally linked to other systems. For example, if a school requires students to perform community service, it should recognize service activities done under the auspices of a Boy Scout troop or religious youth group, provided they meet certain standards. Finally a system endures; it is not dependent on year-to-year allocations of "soft money."

Our hope for this book is that it will give youth development practitioners some information, ideas, sources and models to use in trying to build youth development 
systems. We have organized the book principally around the settings youth inhabit, believing that this fits with the way in which practitioners work. They are usually associated with one or more of these settings. However, as we planned a volume that would be brief enough to be usable, we realized that most readers would find the chapters on the settings they know best to be less informative for them than chapters on other settings. We urge readers to consult chapters on the settings they do no know well, to learn about and thereby work more effectively with people in them who share the goals and principles of youth development.

We also made a choice not to include separate chapters on two important topics: youth participation and differences by race, ethnicity, class, and gender. Like the policy topic, we believe these issues are best understood in relation to the content of each chapter. Therefore, we asked chapter authors to discuss them. We do return to these issues again in the concluding chapter. 
Table 1.2

40 Developmental Assets

Category Asset Name and Definition

Support

1. Family Support-Family life provides high levels of love and support.

2. Positive Family Communication-Young person and her or his parent(s) communicate.

3. Other Adult Relationships-Young person receives support from three or more nonparent adults.

4. Caring Neighborhood-Young person experiences caring neighbors.

5. Caring School Climate-School provides a caring, encouraging environment.

6. Parent Involvement in Schooling-Parent(s) are actively involved in helping young person succeed in school. Empowerment

7. Community Values Youth-Young person perceives that adults in the community value youth.

8. Youth as Resources-Young people are given useful roles in the community.

9. Service to Others-Young person serves as in the community one hour or more per week.

10. Safety-Young person feels safe at home, school, and in the neighborhood.

Boundaries \& Expectations

11. Family Boundaries-Family has clear rules and consequences and monitors the young person's whereabouts.

12. School Boundaries-School provides clear rules and consequences.

13. Neighborhood Boundaries-Neighbors take responsibility for monitoring young people's behavior.

14. Adult Role Models-Parent(s) and other adults model positive, responsible behavior.

15. Positive Peer Influence-Young person's best friends model responsible behavior.

16. High Expectations-Both parent(s) and teachers encourage the young person to do well.

Constructive Use of Time

17. Creative Activities-Young person spends three or more hours per week in sports, clubs, or organizations at school and/or in the community.

18. Youth Programs-Young person spends three or more hours per week in sports, clubs, or organizations at school and/or in the community.

19. Religious Community-Young person spends one or more hours per week in activities in a religious institution.

20. Time at Home-Young person is out with friends "with nothing special to do" two or fewer nights per week.

Commitment to Learning

\section{Internal Assets}

21. Achievement Motivation-Young person is motivated to do well in school.

22. School Engagement-Young person is actively engaged in learning.

23. Homework-Young person is actively engaged in learning.

24. Bonding to School-Young person cares about her or his school.

25. Reading for Pleasure-Young person reads for pleasure three or more hours per week.

Positive Values

26. Caring-Young person places high value on helping other people.

27. Equality and Social Justice-Young person places high value on promoting equality and reducing hunger and poverty.

28. Integrity-Young person acts on convictions and stands up for her or his beliefs.

29. Honesty-Young person "tells the truth even when it is not easy."

30. Responsibility-Young person accepts and takes person responsibility.

31. Restraint-Young person believes it is important not to be sexually active or to use alcohol or other drugs.

Social Competencies

32. Planning and Decision Making-Young person knows how to plan ahead and make choices.

33. Interpersonal Competence-Young person has empathy, sensitivity, and friendship skills.

34. Cultural Competence-Young person has knowledge of and comfort with people of different cultural/racial/ethnic backgrounds.

35. Resistance Skills-Young person can resist negative peer pressure and dangerous situations.

36. Peaceful Conflict Resolution-Young person seeks to resolve conflict nonviolently.

Positive Identity

37. Personal Power-Young person feels he or she has control over "things that happen to me."

38. Self-Esteem-Young person reports having a high self-esteem.

39. Sense of Purpose-Young person reports that "my life has a purpose."

40. Positive View of Personal Future-Young person is optimistic about his or her personal future.

Source: (1997 by Search Institute, www.search-institute.org. This page reproduced, with permission, for educational, noncommercial use only.

Note: Search Institute has identified the above building blocks of healthy development that help young people grow up healthy, caring, and responsible. 
Table 1.3

Features of Positive Developmental Settings

\begin{tabular}{|c|c|c|}
\hline & Descriptors & Opposite Poles \\
\hline $\begin{array}{l}\text { Physical and } \\
\text { Psychological } \\
\text { Safety }\end{array}$ & $\begin{array}{l}\text { Safe and health-promoting facilities; and practices that } \\
\text { increase safe peer group interaction and decrease unsafe } \\
\text { or confrontational peer interactions. }\end{array}$ & $\begin{array}{l}\text { Physical and health, dangers; fear; } \\
\text { feeling of insecurity; sexual and } \\
\text { physical harassment; and verbal } \\
\text { abuse }\end{array}$ \\
\hline $\begin{array}{l}\text { Appropriate } \\
\text { Structure }\end{array}$ & $\begin{array}{l}\text { Limit setting; clear and consistent rules and expectations; } \\
\text { firm-enough control; continuity and predictability; clear } \\
\text { boundaries; and age-appropriate monitoring. }\end{array}$ & $\begin{array}{l}\text { Chaotic; disorganized; laissez-faire; } \\
\text { rigid; over controlled; and autocratic. }\end{array}$ \\
\hline $\begin{array}{l}\text { Supportive } \\
\text { Relationships }\end{array}$ & $\begin{array}{l}\text { Warmth; closeness; connectedness; good } \\
\text { communication; caring; support; guidance; secure } \\
\text { attachment; and responsiveness. }\end{array}$ & $\begin{array}{l}\text { Cold; distant; over controlling; } \\
\text { ambiguous support; untrustworthy; } \\
\text { focused on winning; inattentive; } \\
\text { unresponsive; and rejecting. }\end{array}$ \\
\hline $\begin{array}{l}\text { Opportunities to } \\
\text { Belong }\end{array}$ & $\begin{array}{l}\text { Opportunities for meaningful inclusion, regardless of } \\
\text { one’s gender, ethnicity, sexual orientation, or disabilities; } \\
\text { social inclusion, social engagement, and integration; } \\
\text { opportunities for sociocultural identity formation; and } \\
\text { support for cultural and bicultural competence. }\end{array}$ & $\begin{array}{l}\text { Exclusion; marginalization; and } \\
\text { intergroup conflict. }\end{array}$ \\
\hline $\begin{array}{l}\text { Positive Social } \\
\text { Norms }\end{array}$ & $\begin{array}{l}\text { Rules of behavior; expectations; injunctions; ways of } \\
\text { doing things; values and morals; and obligations for } \\
\text { service. }\end{array}$ & $\begin{array}{l}\text { Normlessness; anomie; laissez-faire } \\
\text { practices; antisocial and amoral } \\
\text { norms; norms that encourage } \\
\text { violence; reckless behavior; } \\
\text { consumerism; poor health practices; } \\
\text { and conformity. }\end{array}$ \\
\hline $\begin{array}{l}\text { Support for } \\
\text { Efficacy and } \\
\text { Mattering }\end{array}$ & $\begin{array}{l}\text { Youth based; empowerment practices that support } \\
\text { autonomy; making a real difference in one's community; } \\
\text { and being taken seriously. Practice that includes } \\
\text { enabling, responsibility granting, and meaningful } \\
\text { challenge. Practices that focus on improvement rather } \\
\text { than on relative current performance levels. }\end{array}$ & $\begin{array}{l}\text { Unchallenging; over controlling; } \\
\text { disempowering; and disabling. } \\
\text { Practices that undermine motivation } \\
\text { and desire to learn, such as excessive } \\
\text { focus on current relative performance } \\
\text { level rather than improvement. }\end{array}$ \\
\hline $\begin{array}{l}\text { Opportunities for } \\
\text { Skill Building }\end{array}$ & $\begin{array}{l}\text { Opportunities to learn physical, intellectual, } \\
\text { psychological, emotional, and social skills; exposure to } \\
\text { intentional learning experiences; opportunities to learn } \\
\text { cultural illiteracies, media literacy, communication skills, } \\
\text { and good habits of mind; preparation for adult } \\
\text { employment; and opportunities to develop social and } \\
\text { cultural capital. }\end{array}$ & $\begin{array}{l}\text { Practices that promote bad physical } \\
\text { habits and habits of mind; and } \\
\text { practices that undermine school and } \\
\text { learning. }\end{array}$ \\
\hline $\begin{array}{l}\text { Integration of } \\
\text { Family, School, } \\
\text { and Community } \\
\text { Efforts }\end{array}$ & $\begin{array}{l}\text { Concordance; coordination; and synergy among family, } \\
\text { school, and community. }\end{array}$ & $\begin{array}{l}\text { Discordance; lack of } \\
\text { communications; and conflict. }\end{array}$ \\
\hline
\end{tabular}

Source: Adapted from National Research council and Institute of Medicine (2002), Table 4-1, pp. 90-91. Reprinted with permission from Community Programs to Promote Youth Development.

(C)2002 by the National Academy of Sciences, Washington, DC. 


\section{Additional Resources on Youth Development}

The American Youth Policy Forum is an excellent source of policy-related material and other information. Available at: http://www.aypf.org/index.htm.

The Center for Youth Development and Policy Research has helped shift the public debate from youth problems to youth development and makes resources available. Available at: www.cyd.aed.org.

Child Trends has a large and diverse list of publications, including research papers, research briefs, literature reviews, and a growing collection of "what works" interactive tables that identify programs proven by research to be effective in promoting child and youth development. They also have an on-line data bank that offers continuously updated trend data with the latest national estimates for all indicators, including downloadable graphics and tables. See especially, American Teens: A Special Look at "What Works" in Adolescent Development. Available at: http://www.childtrends.org.

Community Youth Development is a journal published by the Institute for Just Communities (IJC) and the Institute for Sustainable Development, Heller School of Social Policy and Management, Brandeis University, in collaboration with the national Association of Extension 4-H Agents (NAE4-HA). Available at: http://www.cydjournal.org/.

CYFERnet is a Web site containing program materials, research, and other information from land grant universities and county cooperative extension offices across the country. Available at: http://www.cyfernet.org//.

The Forum for Youth Investment (Karen Pittman) has a wealth of information. Their newsletter is always valuable. Available at: http://www.forumforyouthinvestment.org/.

The National Training Institute for Community Youth Work provides curricula and training to strengthen youth worker practice. Available at: www.nti.aed.org.

The National Youth Development Information Center is maintained by the National Collaboration for Youth, whose members include the national 4- $\mathrm{H}$ Council and other major youth-serving organizations. It contains a wealth of information on programs, funding, and research. Available at: http://www.nydic.org/nydic/.

Public/Private Ventures conducts excellent research on youth programs. Available: http://www.ppv.org.

The Search Institute (Peter Benson) promotes community youth development using its 40-assets framework. It provides support to communities and extensive research. Available at: http://www.search-institute.org/.

The Social Development Research Group, University of Washington School of Social Work, is the origin of "Communities That Care" (Catalano \& Hawkins), the best source for youth programs that have been validated by research. Available at: http://depts.washington.edu/sdrg/. A commercial publisher handles some of their materials: http://www.channing-bete.com/positiveyouth/. 


\section{Notes}

1. S.F. Hamilton devised and contributed this definition to a New York State policy statement (Partners for Children and Adolescent Project Team, 2000). He later found a parallel three-part definition on the Web site of the National Youth Development Information Center (www.nydic.org), attributed to Edginton \& deOlivera (1995, Spring), “A Model of Youth Work Orientations,” Humanics, pp. 3-7.

2. Pittman, Irby, and Ferber (2000) distinguish the following domains: cognitive, social, physical, emotional, personal, civic, and vocational development.

\section{References}

Benson, P.L. (1997). All kids are our kids: What communities must do to raise caring and responsible children and adolescents. San Francisco: Jossey-Bass.

Bronfenbrenner, U. (1979). The ecology of human development: Experiment by nature and design. Cambridge, MA: Harvard University Press.

Bronfenbrenner, U., \& Morris, P. (1998). The ecology of developmental processes. In R.M. Lerner (Ed.), Handbook of child psychology: Vol.1. Theoretical models of human development ( $5^{\text {th }}$ ed.). New York: Wiley.

Catalano, R.F., Berglund, L.M., Ryan, J.A.M., Lonczak, H.S., \& Hawkins, J.D. (1998). Positive youth development in the United States: Research findings on evaluations of positive youth development programs. Report prepared for U.S. Department of Health and Human Services, Office of the Assistant Secretary for Planning and Evaluation, and the National Institute for Child Health and Human Development. (Available at: http://aspe.os.dhhs.gov/hsp/positiveyouthdev99/)

Catalano, R.F., \& Hawkins, J.D. (1996). The social development model: A theory of antisocial behavior. In J.D. Hawkins (Ed.), Delinquency and crime: Current theories (pp. 149-197). New York: Cambridge University Press.

Convention on the Rights of the Child. (1989). Retrieved on March 17, 2003, from http://www.unicef.org/crc/crc.htm.

Developmental Research and Programs, Inc. (2000). Communities That Care: Prevention strategies: A research guide to what works. Seattle, WA: Author.

Dewey, J. (1938). Experience and education. New York: Collier.

Dryfoos, J. (1990). Adolescents at risk: Prevalence and prevention. New York: Oxford University Press.

Hamilton, M.A., \& Hamilton, S.F. (1999). Building strong school-to-work systems: Illustrations of key components. Washington, DC: U.S. Government Printing Office. (Also available at: http://www.human.cornell.edu/youthwork/)

Jessor, R., \& Jessor, S.L. (1977). Problem behavior and psychosocial development: A longitudinal study of youth. New York: Academic Press.

Kohlberg, L., \& Mayer, R. (1972). Development as the aim of education. Harvard Educational Review, 42, 449-496.

Maslow, A.H. (1970). Motivation and personality. New York: Harper \& Row. 
National Research Council and Institute of Medicine. (2002). Promoting positive youth development in New York State: Moving from dialogue to action. Albany, NY: Author. (Available at http://www.nyspartnersforchildren.org/teen.htm)

Pittman, K., Irby, M., \& Ferber, T. (2000). Unfinished business: Further reflections on a decade of promoting youth development. Washington, DC: Forum for Youth Investment.

Pittman, K., Irby, M., Tolman, J., Yohalem, N., \& Ferber, T. (2002). Preventing problems, promoting development, encouraging engagement: Competing priorities or inseparable goals? Washington, DC: Forum for Youth Investment.

Rhodes, J.E., Reddy, R., \&Grossman, J.B. (2002). Volunteer mentoring relationships with minority youth: An analysis of same versus cross-race matches. Journal of Applied Social Psychology, 32, 2114-2133.

Scales, P.C., \& Leffert, N. (1999). Developmental assets: A synthesis of the scientific research on adolescent development. Minneapolis, MN: Search Institute.

Villarruel, F.A., Perkins, D.F., Borden, L.M., \& Keith, J.G. (Eds.). (2003). Community youth development: Programs, policies, and practices. Thousand Oaks, CA: Sage

Whitlock, J.L., \& Hamilton, S.F. (2003). The role of youth surveys in community youth development initiatives. Applied Developmental Science, 7(1) 39-51.

Zeldin, S., McDaniel, A.K., Topitzes, D., \& Calvert, M. (2000). Youth in decision making: A study on the impacts of youth on adults and organizations. Chevy Chase, MD: National 4-H Council.

\section{SOURCE (Reprinted with permission):}

Hamilton, S.F., Hamilton, M.A., \& Pittman, K. Principles for Youth Development. In S.F. Hamilton \& M.A. Hamilton (Eds.) 2004, The Youth Development Handbook: Coming of Age in American Communities (pp.3-22). Thousand Oaks: Sage Publications, Inc. 